\title{
Particle Size Refinement of Zn Electrodeposits in Alkaline Zincate Solutions with Polyethylene Glycol and Tween 80
}

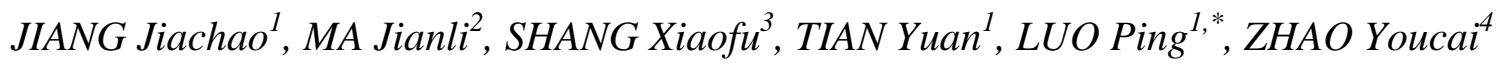 \\ ${ }^{1}$ School of Environment Science and Spatial Informatics, China University of Mining and \\ Technology, Xuzhou 221116, Jiangsu, Peoples R China \\ ${ }^{2}$ Tianjin Academy of Environmental Science, Tianjin, Peoples R China \\ ${ }^{3}$ Tianjin United Environmental Engineering Design Company Limited, Tianjin, Peoples R China. \\ ${ }^{4}$ The State Key Laboratory of Pollution Control and Resource Reuse, Tongji University, Shanghai \\ 200092, Peoples R China. \\ *E-mail: ping.luo@live.cn
}

doi: $10.20964 / 2017.02 .44$

Received: 2 November 2016 / Accepted: 23 December 2016 / Published: 30 December 2016

The alkaline zinc electrowinning process can directly recover powdery $\mathrm{Zn}$ metal from oxidized zinc ores and industrial wastes. However, the industrial-scale practice shows that the $\mathrm{Zn}$ powders produced generally have a broad particle size distribution, and further milling is required prior to applications. In this study, the effects of two kinds of organic additives, polyethylene glycol (PEG) and tween 80, on the particle size refinement of $\mathrm{Zn}$ deposits in alkaline electrolytes were investigated for the first time. The results show that both of the additives dramatically reduced the particle size of $\mathrm{Zn}$ deposits and increased the weight percentage of undersized product $(<150 \mu \mathrm{m})$ while the current efficiency remained $>98 \%$ and the $\mathrm{Zn}$ purity was $>99 \%$. From results of scanning electron microscopy (SEM), energy-dispersive $\mathrm{x}$-ray spectroscopy (EDS), X-ray diffraction (XRD) analysis, and cyclic voltammetry $(\mathrm{CV})$ experiments, the possible explanation is that the addition of tween 80 and/or PEG increased cathodic overpotential and subsequently increased the $\mathrm{Zn}$ nucleation rate and restrained the $\mathrm{Zn}$ grain growth. Eventually, an increased amount of $\mathrm{Zn}$ deposits with fine 3-D structure were produced, and a higher $\mathrm{Zn}$ deposit refinement was achieved. Orthogonal experiments were designed to investigate the co-effects of the additives and the electrolysis parameters: electrolyte temperature, current density, and electrolysis time. The optimum particle size refinement was obtained when 5 $\mathrm{mg} / \mathrm{L}$ tween 80 and $100 \mathrm{mg} / \mathrm{L}$ PEG were added to the alkaline electrolyte, and the electrolysis was conducted for $10 \mathrm{~min}$ at $0{ }^{\circ} \mathrm{C}$ with a current density of $800 \mathrm{~A} / \mathrm{m}^{2} ; 99.82 \mathrm{wt} . \%$ of $<150 \mu \mathrm{m}$ particles and 52.94 wt. $\%$ of $<45 \mu \mathrm{m}$ particles were observed.

Keywords: Polyethylene glycol; Tween 80; Particle Size Refinement; Zn powder; Alkaline 


\section{FULL TEXT}

(C) 2017 The Authors. Published by ESG (www.electrochemsci.org). This article is an open access article distributed under the terms and conditions of the Creative Commons Attribution license (http://creativecommons.org/licenses/by/4.0/). 